\title{
$\mathrm{DC}$ 마이크로그리드의 동작분석을 위한 하드웨어 시뮬레이터 개발
}

李知憲 ${ }^{*}$, 金元溶 ${ }^{*}$, 金鍾元 ${ }^{\star *}$, 韓炳文 $^{\dagger}$

\section{Development of Hardware Simulator for Operation Analysis of DC Microgrid}

Ji-Heon Lee, Won-Yong Kim, Jong-Won Kim, and Byung-Moon Han

요 약

본 논문에서 $\mathrm{DC}$ 마이크로그리드의 동작분석을 위한 하드웨어 시뮬레이터의 개발에 관해 기술하고 있다. 이 하드 웨어 시뮬레이터는 분산전원으로 풍력발전, 태양광 발전, 연료전지를, 그리고 에너지저장으로 슈퍼커패시터, 배터리 를 포함하고 있다. 또한 전체시스템의 에너지관리와 상태모니터링을 수행하는 중앙제어기를 포함하고 있어 이더넷 을 기반으로 한 통신을 통해 각 분산전원과 에너지저장에 탑재된 하위제어기와 연계되어있다. 개발한 하드웨어 시 뮬레이터는 실제 상황을 고려한 $\mathrm{DC}$ 마이크로그리드의 성능분석에 활용될 것으로 기대된다.

\section{ABSTRACT}

This paper describes the development of hardware simulator for the operation analysis of DC microgrid. The hardware simulator consists of several distributed power sources such as a wind power generation, solar power and fuel cell, and two energy storages such as a supercapacitor and battery. The main controller which performs a role of energy management and state monitoring is connected with the local controller in each power source and storage through ethernet-based communication link. The developed hardware simulator can be utilized to analyze the performance DC microgrid with practical manner.

Key Words : DC Micro-grid, DC Distribution, Energy Management System, Distributed Generation, Energy Storage

\section{1. 서 론}

마이크로그리드는 신재생발전기, 에너지저장, 부하가 결합하여 교류 전력망과 연계된 소규모 전력망을 의미하 며 구성요소들을 교류로 연결한 $\mathrm{AC}$ 마이크로그리드와 직류로 연결한 DC 마이크로그리드로 구분할 수 있다.

\footnotetext{
†교신저자 : 정회원, 명지대 전기공학과 교수

E-mail : erichan@mju.ac.kr

"정회원, 명지대 전기공학과 박사과정

**학생회원, 명지대 전기공학과 석사과정

접수일자 : 2011. 9. $21 \quad$ 1차 심사 : 2011. 10. 4

2차 심사 : 2011. 10. $25 \quad$ 심사완료 : 2011. 11. 1
}

$\mathrm{AC}$ 마이크로그리드는 기존의 배전망을 그대로 활용 하는 장점이 있으나, 동기화, 안정도, 무효전력 문제를 야기한다.

그러나 $\mathrm{DC}$ 마이크로그리드는 동기화, 안정도, 무효 전력소모에 대한 문제가 없으며 각 전원에서 생산되는 전력을 연계함에 있어 2단계 전력변환이 필요 없어 시 스템의 손실과 비용이 낮은 장점을 갖는다. 또한 최근 사용이 급증하고 있는 디지털 부하는 원래 직류전원을 필요로 하여 $\mathrm{DC}$ 마이크로그리드에 대한 관심이 집중 되고 있다 ${ }^{[1,2,3]}$.

마이크로그리드의 동작을 제어하는 방법은 크게 두 가지로 분류할 수 있다. 
먼저 통신을 사용하지 않고 각 컨버터가 연계 $\mathrm{DC}$ 단 전압을 측정하여 Droop 제어를 수행하는 방식으로, 자 율적으로 시스템을 제어하는 것이다 ${ }^{[4,5]}$. 이 방식은 상 시 존재하는 순환전류로 인한 효율의 문제, $\mathrm{DC}$ 버스 전압의 빈번한 과도 발생과 통신을 사용하지 않음으로 인해 기기 간의 상태전달이 안돼는 점, 또한 마이크로 그리드의 느린 응답성 및 안정도에 대한 단점이 있다.

다른 하나는 중앙제어기를 두고 분산전원, 에너지저 장, 부하, 연계전력망의 전력량을 실시간으로 측정하여 운전모드에 따라 알고리즘에 의해 시스템을 제어하는 방식이 있다. 이 방식은 전력량을 측정하기위한 센서 와 측정된 데이터를 중앙제어기로 전송하는 통신망을 필요로 한다 ${ }^{[6,7,8]}$. 고속 통신망을 사용함으로 인해 중앙 에서 각 기기들의 정보를 신속하게 전달받아 마이크로 그리드를 운용함에 있어서 높은 신뢰도와 안정성을 얻 을 수 있으며 정확한 모니터링 시스템으로 인하여 사 용자에게 좀 더 정확한 정보를 전달 할 수 있다는 장 점이 있다.

본 논문에서는 분산전원, 에너지저장, 부하, 그리고 교류연계전력망으로 구성된 $\mathrm{DC}$ 마이크로그리드에서 신뢰도 높은 통신망을 기반으로 하여 실시간으로 전체 시스템의 동작을 모의할 수 있는 하드웨어 시뮬레이터 의 개발에 관해 기술하고 있다. 개발한 DC 마이크로 그리드 시뮬레이터는 연계되는 기기들의 최적운전을 통해 고효율이 기대가능하며, 계통연계시나 단독운전 시 어느 경우에도 부하에 끓임없이 고품질의 전력 공 급이 가능하다.

\section{2. $\mathrm{DC}$ 마이크로그리드의 구성}

본 논문에서는 다양한 분산전원 중에서 그림 1 에 보 인 것처럼 분산전원으로는 출력조절이 불가능한 풍력 과 태양광, 출력조절이 가능한 연료전지를 사용하였고, 에너지저장으로는 슈퍼커패시터와 배터리가 사용되었 다. 컨버터의 토폴로지 와 파라미터 및 사용한 분산전 원의 세부 설명은 참고문헌 [9]에 자세히 기술되어 있 다. 각각의 전력변환기들은 하위제어기에 의하여 제어 되며 필요한 변수들을 상위제어기와 송수신한다. 상위 제어기에는 에너지 관리 시스템이 탑재되어 있으며 모 니터링 및 마이크로그리드 제어를 관장하고 각 컨버터 에 제어 지령치와 구동명령을 하달한다.

그림 2는 제안하는 통신 연계 개념도이며 소규모 CAN그룹과 IEC 61850통신을 위한 두 개의 CAN 통 신이 사용된다. 소규모 $\mathrm{CAN}$ 그룹은 비교적 설치장소에

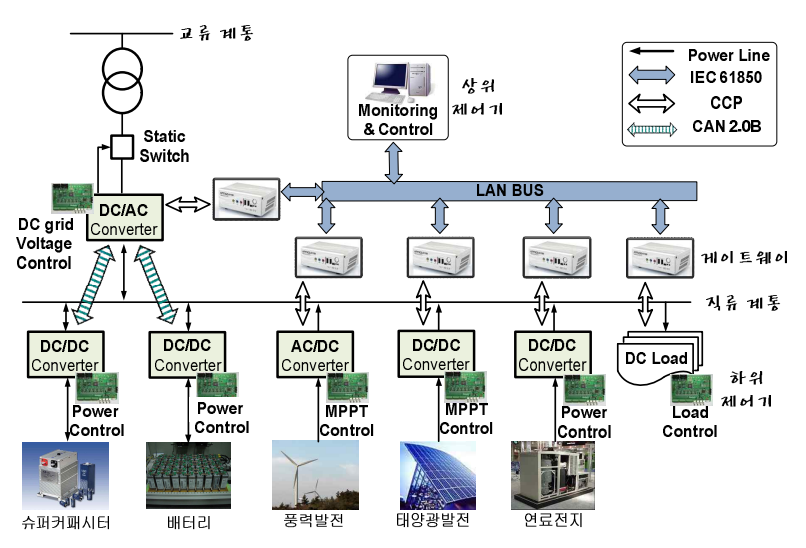

그림 $1 \mathrm{DC}$ 마이크로그리드의 구성

Fig. 1 Configuration of DC Micro-grid

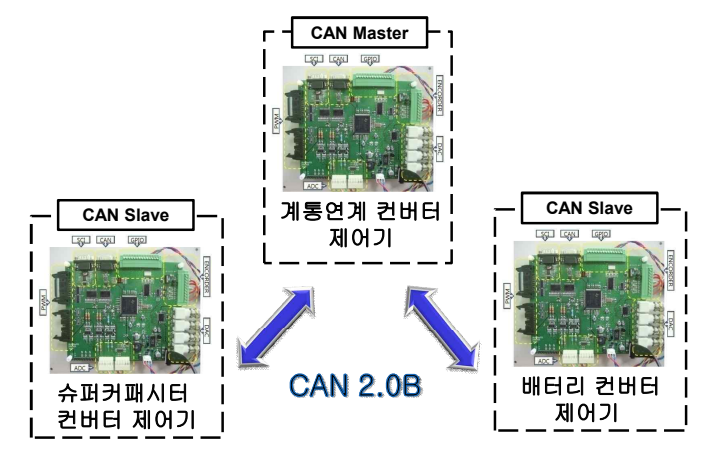

(a) 소규모 CAN 그룹

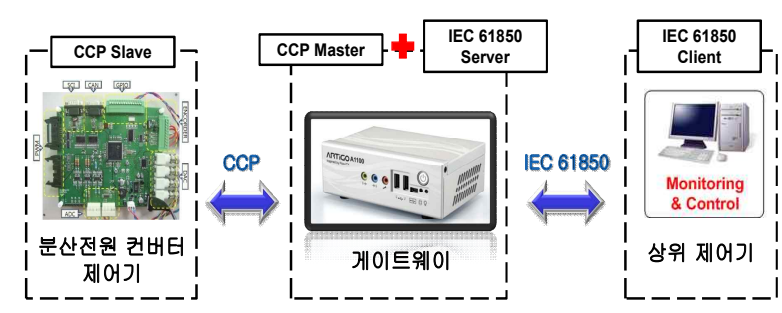

(b) CCP-to-IEC 61850 통신 연결

그림 2 통신 시스템 구성

Fig. 2 Configuration of Communication System

구애받지 않는 계통연계 인버터와 에너지 저장장치로 구성되고 $\mathrm{CAN} 2.0 \mathrm{~B}$ 를 사용하며 게이트웨이를 거치지 않고 직접 하위 제어기 간 연계된다.

소규모 $\mathrm{CAN}$ 그룹에서의 고속통신에 의하여 에너지 저장요소들의 빠른 모드전환과 전력 지령 수신이 가능 해지므로 마이크로그리드의 응답성 및 안정도를 높이 는데 크게 기여한다.

분산전원 제어용 하위제어기와 게이트웨이는 $\mathrm{CAN}$ 
통신 중 하나인 $\mathrm{CCP}(\mathrm{Can}$ Calibration Protocol)를 사 용하며 게이트웨이와 위제어기는 IEC 61850을 통해 연계된다. 하위 제어기는 CCP Slave역할을 하며 Gateway는 CCP Master와 IEC 61850 Server의 기능 을 동시에 수행하게 된다. Gateway에서 변환된 IEC 61850 데이터는 LAN BUS를 통해 Client 역할을 수행 하는 상위제어기와 연계된다.

$\mathrm{CAN}$ 은 매 변수의 데이터 범위 및 데이터 형에 따 라 수동으로 프로그래밍을 하지만 $\mathrm{CCP}$ 는 $\mathrm{CCP}$ 라이 브러리를 포함하고 있는 통신 대상의 메모리 번지에 직접 접근하여 변수 값의 수집/변경 작업을 손쉽게 할 수 있다는 장점이 있으므로 분산전원 통신용 프로토콜 에 적합하다.

\section{3. 시스템 특성 분석}

\section{1. 에너지 관리기법}

본 연구에서는 에너지 관리기법을 계통연계 시와 단 독운전 시로 나누어 접근하였으며 그림 3 에 나타내었 다.

그림 3(a)는 계통연계 시에 에너지관리기법에 대한 개념도를 나타낸 것이다. 굵은 선으로 표시한 부하곡 선은 일반적인 하루 동안의 요구량을 표현한 것이다.

분산전원으로부터의 출력이 충분이 커서 부하를 감 당하고 에너지저장에 충전되고도 남는 전력은 계통으 로 보내지며, 분산전원에서의 출력이 부족하고 에너지 저장에서 공급하는 전력도 부하를 감당하지 못할 경우 에는 계통으로부터 전력을 공급받는다.

계통연계 시에 에너지저장은 슈퍼커패시터와 배터리 의 장-단점을 서로 보완하여 안전하고 효율적인 방식 으로 운용한다. 급격하고 적은 전력의 변화는 반응이 빠르지만 에너지 저장량이 적은 슈퍼커패시터가 감당 하며, 긴 시간 동안의 방대한 전력의 변화는 반응은 느리지만 에너지 저장량이 큰 배터리에서 관리하도록 한다.

그림 3(b)에 단독운전시의 에너지 관리기법에 대한 개념도를 나타내었다.

단독운전이 검출되어 계통과 마이크로그리드가 분리 되면 연계용 인버터는 제어의 기능을 잃게 된다. 분산 전원의 전력변환기는 효율적인 운용을 위한 출력제어 를 해야 하므로 슈퍼커패시터에서 $\mathrm{DC}$ 그리드의 일정 전압제어를 수행하면서 급격한 에너지의 변화에 대해 서 보조적 역할을 하고 배터리에서 상시 전력관리를 수행한다.
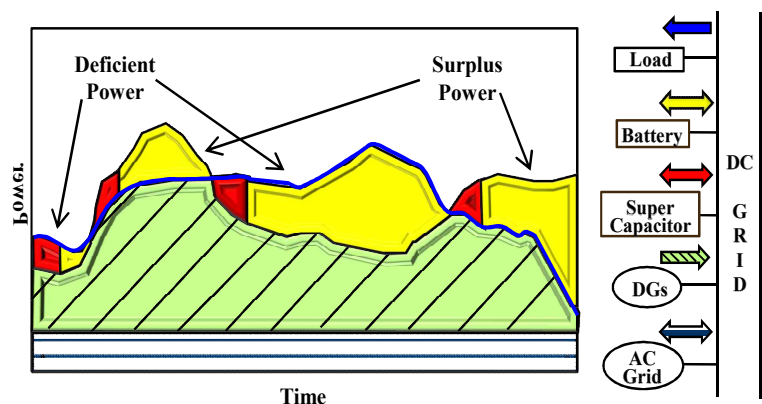

(a)계통연계 운전

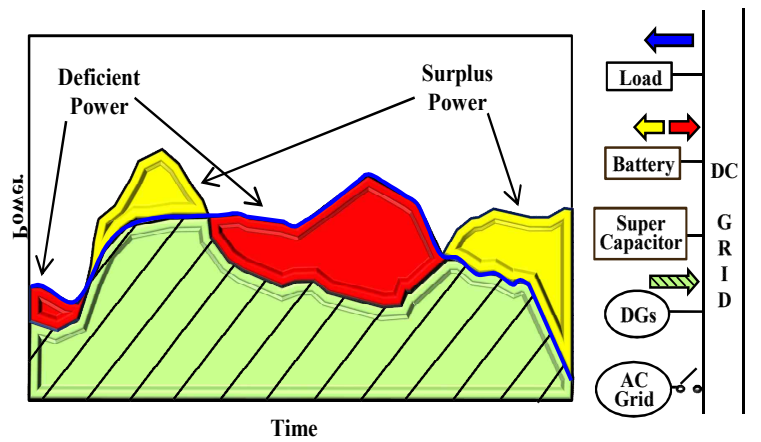

(b) 단독 운전

그림 3 에너지 관리 개념

Fig. 3 Concept of Energy Management

\section{2. 에너지저장의 제어}

그림 4(a)는 계통연계 시 에너지저장의 운용기법에 대해 나타낸 것이다. 여기서, 분산전원 출력의 합을 $\mathrm{P}_{\mathrm{DG}}$, 부하의 수요전력을 $\mathrm{P}_{\mathrm{LOAD}}$, 계통 전력을 $\mathrm{P}_{\mathrm{BULK}}$ 로 정의한다.

$\mathrm{P}_{\mathrm{DG}}$ 가 $\mathrm{P}_{\mathrm{LOAD}}$ 보다 클 경우에 Charge Mode로 동작하 면서 이 때 전력의 지령치는 두 측정값의 차이가 된 다. 먼저 슈퍼커패시터 컨버터가 충전동작을 수행하며 설정한 최대전압까지 증가하면 동작을 멈추고 배터리 컨버터가 이어서 전력관리를 수행한다. 배터리가 $\mathrm{SOC}$ 상한치에 이르게 되면 잉여전력은 계통으로 공급하도 록 한다. $\mathrm{P}_{\mathrm{LOAD}}$ 가 $\mathrm{P}_{\mathrm{DG}}$ 보다 클 경우에는 Discharge Mode로 동작하고 이때 방전되는 전력은 두 측정값의 차이가 된다. 충전 시와 마찬가지로 먼저 슈퍼커패시 터 컨버터가 동작하여 전력을 방전하고 슈퍼커패시터 가 최소전압까지 감소하면 이어서 배터리 컨버터가 동 작하며 배터리가 $\mathrm{SOC}$ 의 하한치에 이르게 되었을 때 부족한 전력은 계통으로부터 공급받도록 한다. 충·방전 동작이 바뀌는 시점에서는 빠르고 정확하게 Mode Change가 이루어 져야 하며 $\mathrm{P}_{\mathrm{ES}}$ 의 부호를 감지하여 Mode Change Index로 사용한다. 


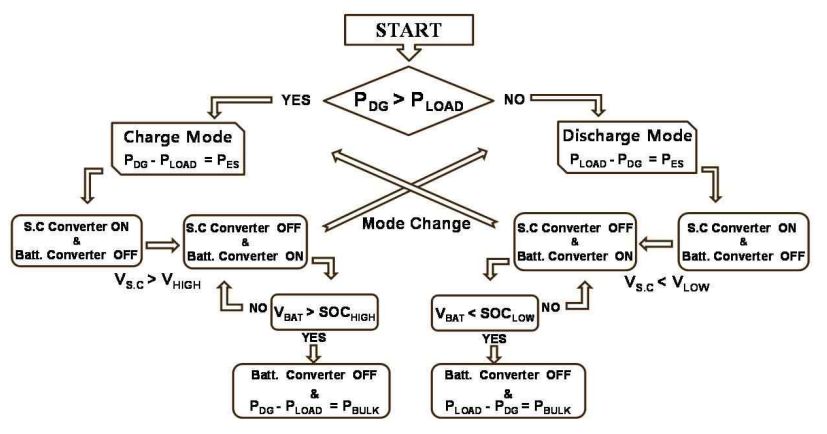

(a) 계통 연계

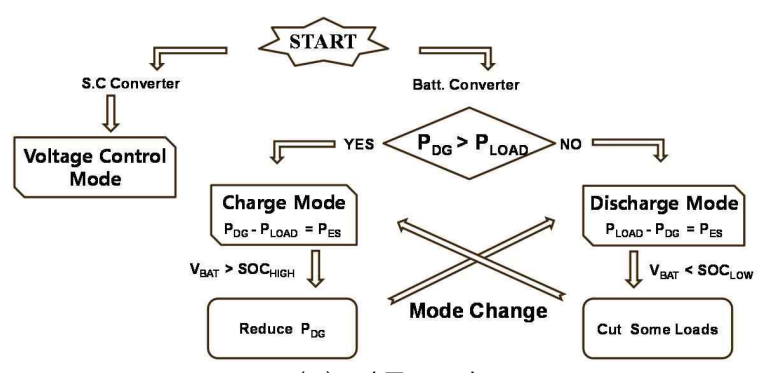

(b) 단독 운전

그림 4 에너지저장 운용 기법

Fig. 4 Operation Method of Energy Starage

그림 4(b) 단독운전 시 에너지저장의 운용기법에 대 하여 나타낸 것이다. 단독운전 동안은 슈퍼커패시터에 서 전압제어와 배터리 컨버터에서 전력제어를 수행한 다. 충전 시 배터리의 $\mathrm{SOC}$ 상한치에 이르면 출력을 조절할 수 있는 분산전원의 컨버터를 제어하여 전체 분산전원의 출력을 줄이도록 한다. 배터리가 방전을 계속하면서 설정한 $\mathrm{SOC}$ 하한치까지 감소하면, 전력을 공급할 수 있는 에너지원이 더 이상 없으므로 중요하 지 않은 부하를 절체하는 로드-쉐딩 기법을 적용한다.

\subsection{DC 마이크로그리드의 제어}

그림 5 는 마이크로그리드에 포함된 각 구성요소의 제어기 구성을 나타낸 것이다.

계통연계인버터는 계통연계 시 전압 기준치를 실측 그리드전압과 비교하여 전압제어기를 통과하여 기준전 류를 생성하고 이 값을 실측 전류와 비교하여 전류제 어기를 거쳐 게이트 펄스를 생성한다.

PV Array는 일사량과 온도에 의해 변동하는 출력을 항상 최대가 되도록 MPPT (Maximum Power Point Tracking)제어를 수행하며 이를 위해 $\mathrm{P} \& \mathrm{O}$ (Perturbation and Observation) 기법을 적용하였다.

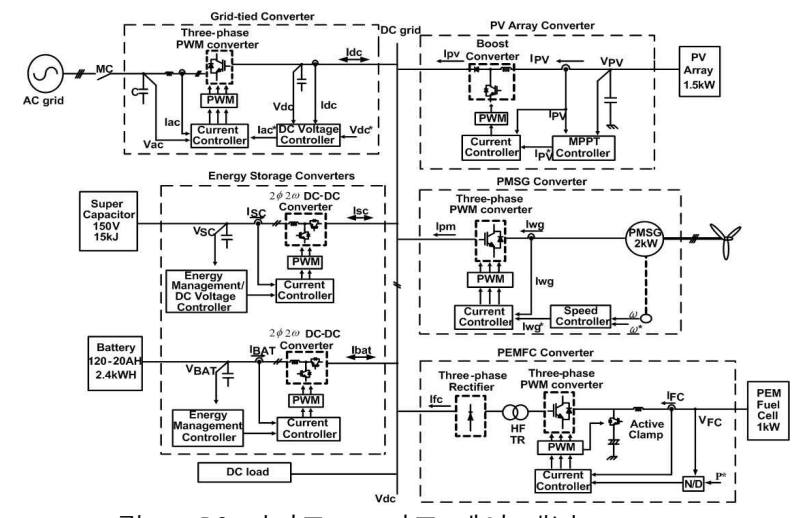

그림 $5 \mathrm{DC}$ 마이크로그리드 제어 개념

Fig. 5 Control Concept of DC micro-grid

PMSG의 삼상 PWM 컨버터는 풍속에 따라 변동하 는 출력을 항상 최대로 그리드에 공급할 수 있도록 제 어를 수행한다. 발전기의 각속도가 일정하도록 전류제 어를 하면 블레이드의 출력계수가 최대로 되어 발전기 의 출력이 최대가 되도록 제어한다.

연료전지는 출력을 조절할 수 있는 에너지원이므로 에너지관리를 고려하여 효율적으로 활용하는 제어가 필요하다. 연료전지의 전력 기준치는 상위 제어기로부 터 전송받게 되며 이를 연료전지의 출력전압으로 나눠 기준전류를 생성하고 이 값과 실측전류를 전류제어기 를 통과시켜 게이트 펄스를 생성한다.

에너지저장장치는 계통연계시와 단독운전시에 따라 전력, 전압제어를 수행한다. 전력제어 시에는 상위 제 어기로부터 전송받은 전력 지령을 에너지 저장장치의 출력전압으로 나누고 이를 양분하여 각 컨버터 leg에 서 추종해야 하는 전류 지령 만들어 내고 실측 전류와 전류제어기를 통과시킨 후 게이트 펄스를 생성한다. 전압제어 시에는 전압 기준치와 실측 전압을 전압 제 어기를 거친 후 전류 레퍼런스를 생성한다. 이하 전류 제어기는 전력 제어와 동일하다.

\section{4. 분산전원 계통연계 실험}

제안하는 $\mathrm{DC}$ 마이크로그리드의 통합시험에 앞서 각 분산전원들의 계통연계 성능을 검증하였다. 각 실험에 는 동일한 계통연계 인버터가 사용되었다.

그림 6 은 태양광 시스템의 계통연계 실험결과이다. $\mathrm{PV}$ Array 출력전력의 주파수가 전압 주파수의 2배임 을 보아 MPPT 제어가 원활히 수행되고 있으며 계통 연계 인버터의 $\mathrm{DC}$ 링크 전압제어와 무효전력제어 성 능을 검증하였다. 
그림 7은 풍력발전 계통연계실험 결과이다. 사용되 는 풍력발전 시뮬레이터는 풍속계와 이를 DSP로 전송 하는 데이터 로거, 벡터 드라이버와 $\mathrm{M}-\mathrm{G}$ SET으로 구 성되어있으며 실제와 유사한 상황을 모의 가능하다. 실험결과를 통해 입력되는 풍속의 변화에 따라서 효율 계수 $\mathrm{CP}$ 는 항상 일정하게 고정되면서 $\mathrm{MPPT}$ 제어가 수행되고 있음을 검증하였다.

그림 8은 연료전지 계통연계 실험결과이다. 연료전 지용 $\mathrm{DC}-\mathrm{DC}$ 컨버터는 전달되는 지령에 따라 전류제 어를 수행하고 있으며 낮은 전류리플과 단일 컨버터로 서 $97 \%$ 의 높은 효율을 보여준다.

그림 9는 에너지 저장장치의 실험결과이다. 입력되 는 지령에 따라 전류제어를 수행하고 있으며 각 상이 정확히 120 도 씩 인터리브 되어 전류리플의 감소효과 를 보이고 있다.

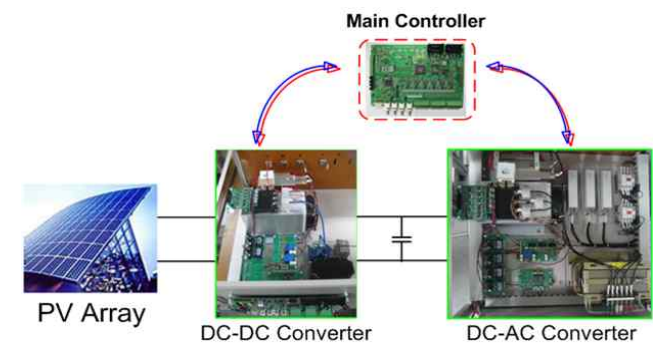

(a) 연계 구성도

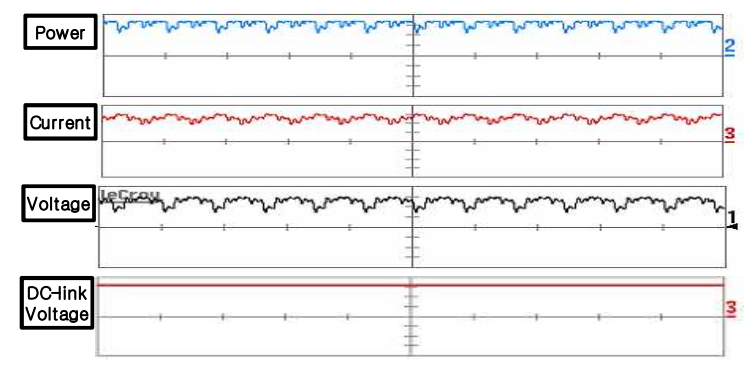

(b) PV Array 출력

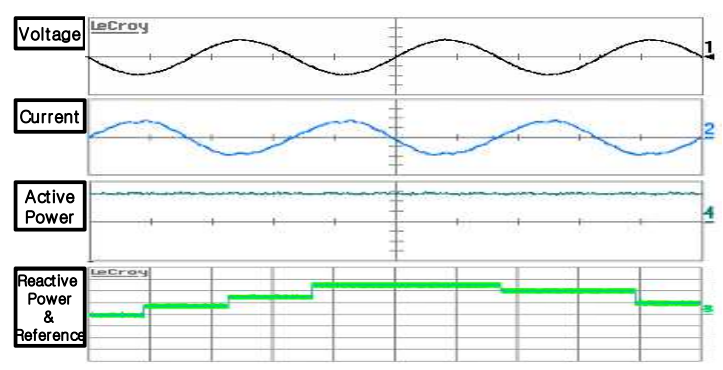

(c) 계통 출력

그림 6 PV Array 계통연계 실험

Fig. 6 Test of Grid-connected PV System

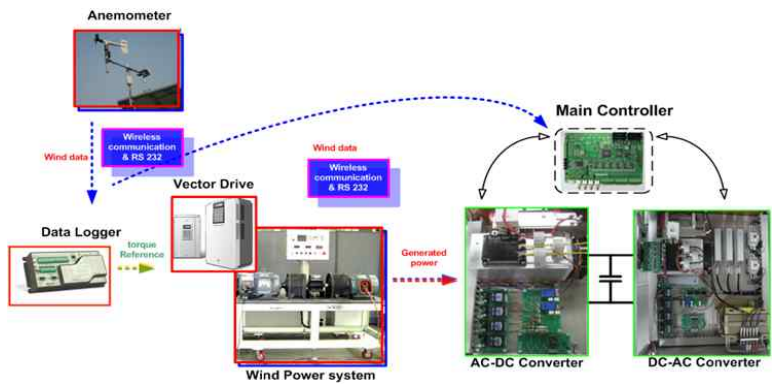

(a) 연계 구성도

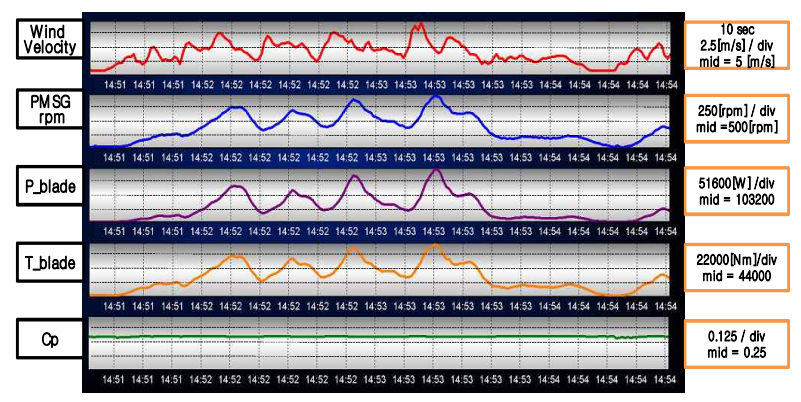

(b) 실험 결과

그림 7 풍력발전 계통연계 실험

Fig. 7 Test of Grid-connected Wind Power System

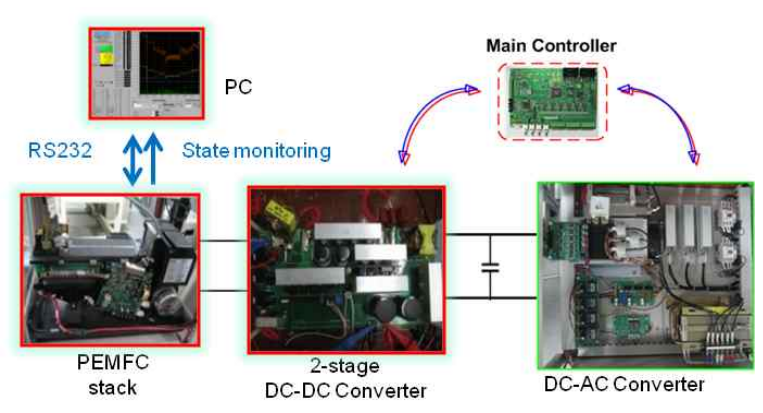

(a) 연계 구성도

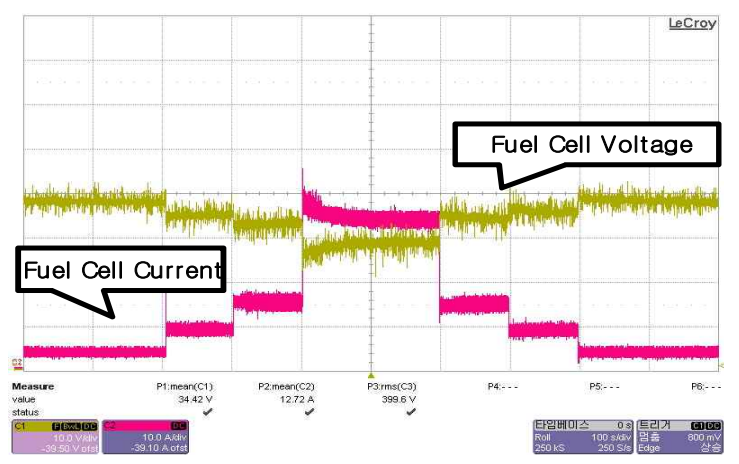

(b)연료전지 출력 


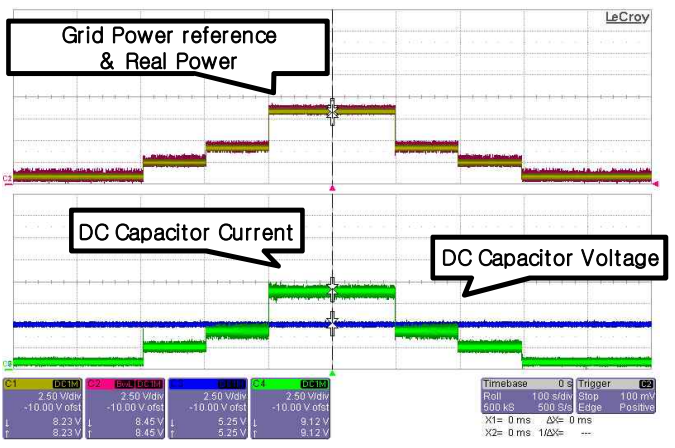

(c) 계통 출력

그림 8 연료전지 계통연계 실험

Fig. 8 Test of Grid-connected Fuel Cell System

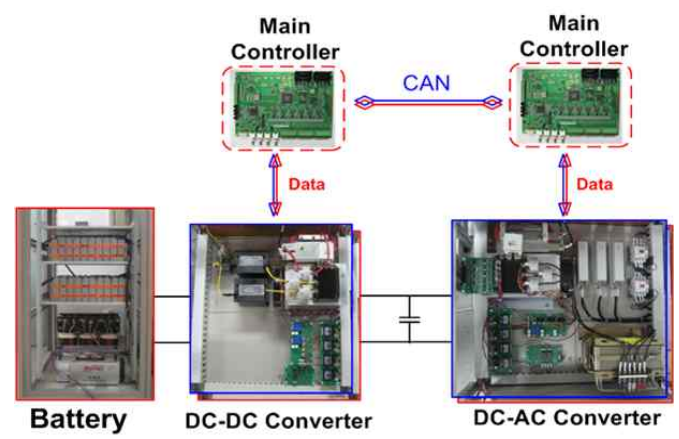

(a) 연계 구성도

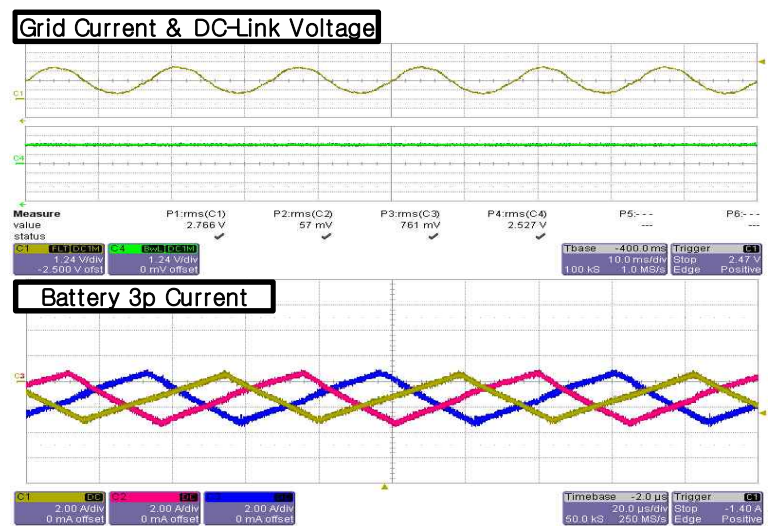

(b) 실험 결과

그림 9 에너지저장 계통연계 실험

Fig. 9 Test of Grid-connected Energy Storage

\section{5. 통합 연계 실험}

그림 10에 $\mathrm{DC}$ 마이크로그리드 통합시험을 위한 하 드웨어 구성 사진을 나타내었다. 순서대로 연료전지 발전장치, 태양광발전 시뮬레이터, $\mathrm{DC}$ 마이크로그리드

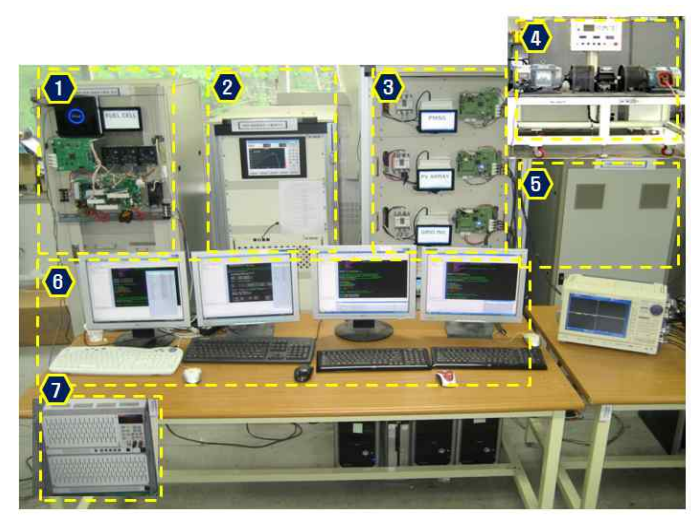

그림 10 구축된 실험환경

Fig. 10 Experiment Set-up

장치, 풍력발전 시뮬레이터, $\mathrm{Ni}-\mathrm{MH}$ 배터리 스택, $\mathrm{DSP}$ 구동 $\mathrm{PC}$, 가변 직류부하이며 여러 파형을 동시에 측정 하기 위하여 $\mathrm{YOKOKAWA}$ 의 $16 \mathrm{CH}$ 스코프를 사용하 였다.

실험 시 중요 점검 항목을 표 1에 나타내었다. 시뮬 레이션을 이용한 특성분석을 토대로 실험을 수행하고 자 하였으며 IEC 61850과 CAN그룹간의 연계에 의한 통신 속도 및 전력 지령치의 스텝 변화 시 과도 상태, 알고리즘에 의한 시퀀스 고속 전환 등을 확인하고자 하였다. 부하는 기저부하를 사용하였으며 분산전원의 출력을 스텝적으로 변화시키면서 과도상태를 확인하고 자 하였다.

표 1 실험 점검 항목

Table 1 Check List in Experiment

\begin{tabular}{|c|c|}
\hline No. & 점검 항목 \\
\hline 1 & 상위제어기와 하위제어기간의 통신 속도 \\
\hline 2 & 충·방전 전환 시 과도상태 \\
\hline 3 & 알고리즘에 의한 시퀀스 변환 \\
\hline 4 & DC 그리드 전압 및 에너지저장 과도상태 \\
\hline 5 & 부하로의 안정적인 전력 공급 \\
\hline 6 & 모드 전환 시의 과도상태 \\
\hline
\end{tabular}

\section{1 통신 시스템}

그림 11 은 제어에 필요한 통신 데이터를 나타낸다. 소그룹 $\mathrm{CAN}$ 그룹 간에는 상위 제어기로부터 제어 지 령 및 구동 명령의 수신이 이루어지며 에너지 저장장 치의 충전상태를 모니터하여 상위제어기로 송신한다.

분산전원 제어기는 출력되는 전력을 전송하고 연료 전지 제어기는 상황에 따라서 바뀌는 전력 지령을 수 신 받으며 부하의 게이트웨이는 실시간으로 소모되는 전력을 상위제어기로 전송한다. 


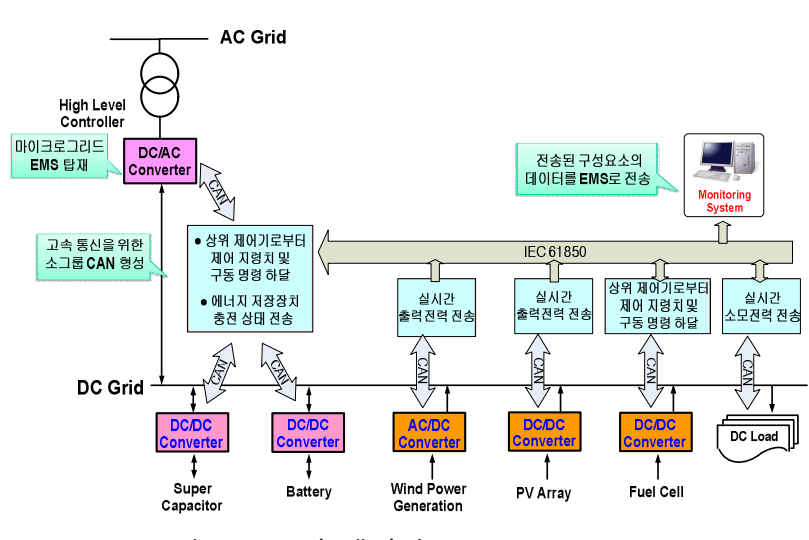

그림 11 통신 데이터

Fig. 11 Communication Data

그림 12 에 통신 시험 결과를 나타내었다. 그림 12(a) 는 소규모 $\mathrm{CAN}$ 그룹의 시험결과로서 계통연계인버터 와 에너지저장장치의 하위제어기 간의 데이터 전송상 황이다.

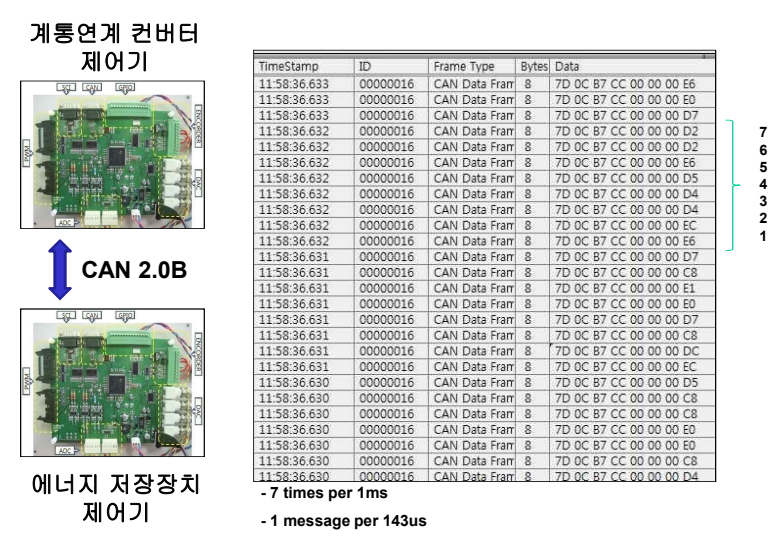

(a) 소규모 CAN 그룹 시험
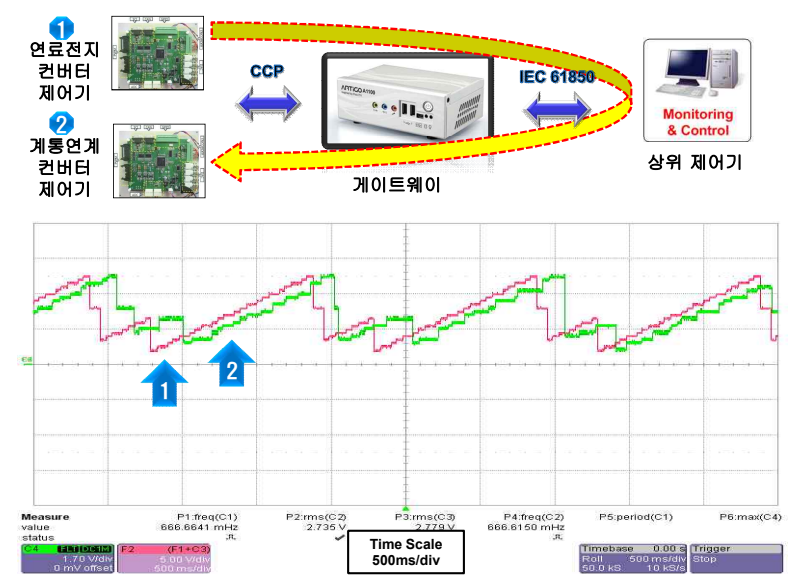

(b) CCP-to-IEC 61850 시험

그림 12 통신 시험

Fig. 12 Communication Test
캔 통신 최대 데이터 길이인 8byte의 메시지를 연속 으로 보내고 있으며 $1 \mathrm{~ms}$ 동안 총 7 회 송·수신 하므로 메시지 1개당 143[usec] 소요가 되며 이는 소규모 $\mathrm{CAN}$ 그룹의 운용에 충분한 시간이다.

그림 12(b)는 CCP-to-IEC 61850 시험 결과이다. 실 제 송수신 딜레이를 측정한 대상은 계통연계 컨버터 제어기와 연료전지 컨버터 제어기이며 데이터 왕복시 간을 측정하였다. 계통연계 컨버터에서 다시 데이터를 수신 받기 까지 걸리는 시간은 $120 \mathrm{~ms}$ 정도이며 이는 $\mathrm{DC}$ 마이크로그리드 계통의 에너지 관리에 충분한 시 간이다.

\section{2 계통연계 실험}

그림 13에 계통연계 실험에 대하여 나타내었으며 그 림 13(a)는 분산전원들의 출력을 보여준다. 위에서부터 분산전원의 출력 합, 태양광 어레이, $\mathrm{PMSG}$, 연료전지 의 출력을 나타낸다. 실험 시나리오는 분산전원 출력 에 관여하는 지령들을 스텝적으로 변화시키면서 분산 전원 출력의 합에 변동을 주도록 구성하여 $\mathrm{DC}$ 마이크 로그리드의 과도상태 및 기기들의 동작특성을 확인하 고자 하였다.

그림 13(b)는 교류계통, 분산전원 출력의 합, 부하전 력 및 $\mathrm{DC}$ 그리드 전압을 나타내며, 배터리 용량이 한 계에 다다랐을 때에 계통으로부터 전력의 공급 및 수 급이 이루어지고 있으며 부하에는 안정된 전력이 공급 되면서 $\mathrm{DC}$ 그리드의 전압은 일정하게 제어되고 있다.

그림 $13(\mathrm{c}),(\mathrm{d})$ 는 에너지 저장의 특성 파형으로서 정 해진 운용범위 안에서 상위제어기로부터의 전력 지령 치와 운용 Flag에 의해 동작하고 있는 것을 확인할 수 있다. 그림 13(e)는 에너지 저장의 동작을 비교하기 위 한 파형으로서 소규모 $\mathrm{CAN}$ 그룹간의 빠른 통신 속도 에 의하여 안정적으로 전력관리를 수행하는 것을 확인 하였다.

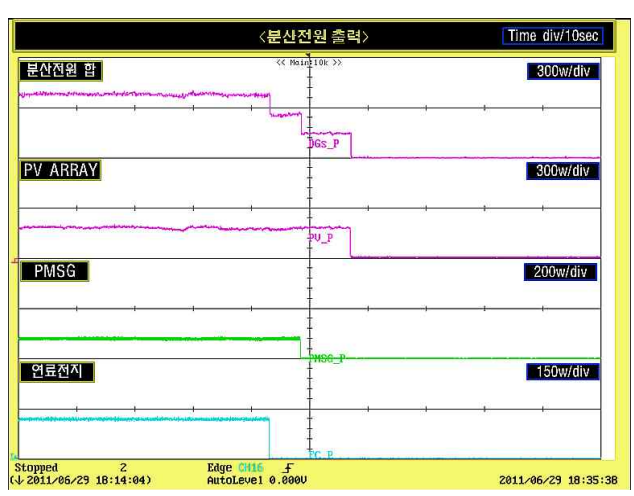

(a) 분산전원 출력 


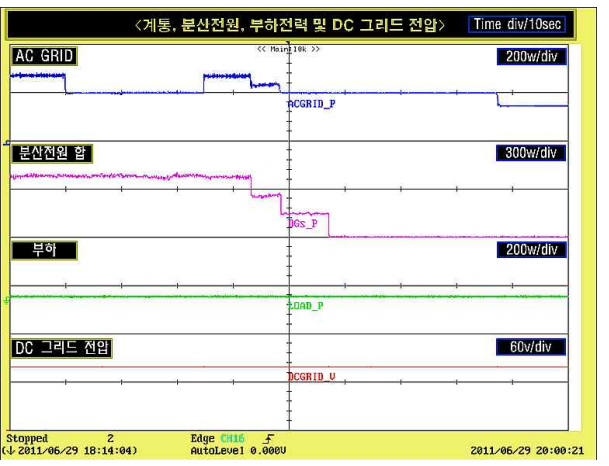

(b) 계통, 분산전원, 부하전력 및 $\mathrm{DC}$ 그리드 전압

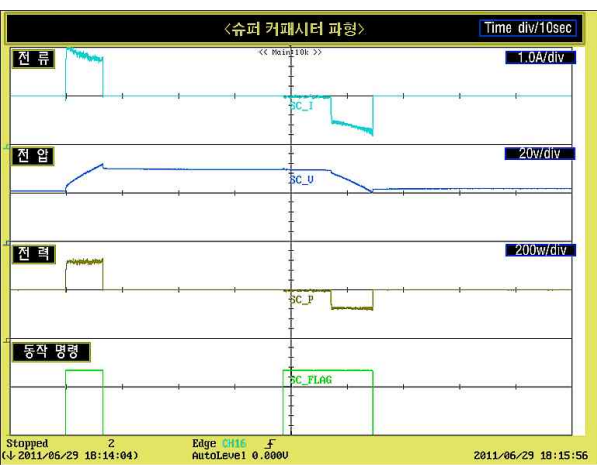

(c) 슈퍼 커패시터 부 파형

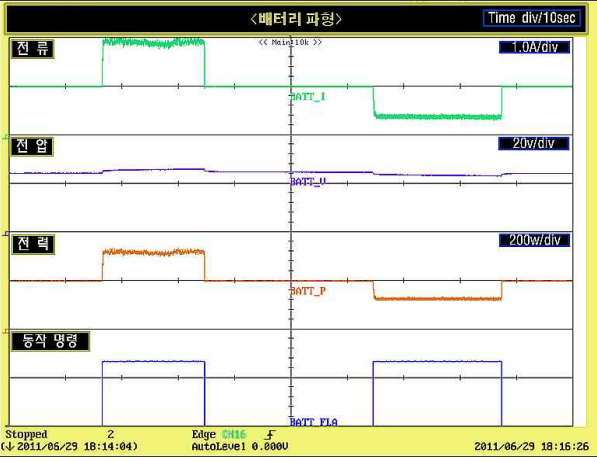

(d) 배터리 부 파형

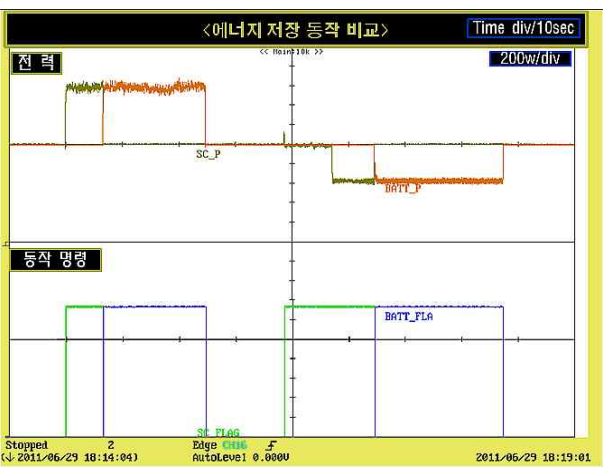

(e) 에너지 저장 동작 비교

그림 13 계통연계 실험 결과

Fig. 13 Experiment Result in Grid-tied Operation

\section{3 단독운전 실험}

그림 14 에 계통연계에서 단독운전으로 전환 시 결과 파형을 나타내었으며 전환 시의 과도 상태를 분석하는 것이 이번 실험의 목적이다. 그림 $14(\mathrm{a})$ 는 계통, 분산 전원, 부하전력 및 $\mathrm{DC}$ 그리드 전압을 나타낸다. 과도 상태를 분석하기 위해 계통에서 기저부하에 전력을 공 급하고 있는 상황에서 단독운전으로 전환되는 시나리 오를 구성하였다. 단독운전이 발생하는 순간 $\mathrm{DC}$ 그리 드의 전압은 과도 없이 일정하게 제어되고 있으며 부 하에 안정적으로 전력공급이 이루어진다. 그림 14(b)에 에너지 저장 동작을 비교하여 나타내었다. 단독운전으 로 전환되는 시점에서 에너지 저장장치들이 동작 명령 을 하달 받아 모드 전환을 시작하고 슈퍼 커패시터는 전압제어를, 배터리는 전력관리를 수행하는 것을 확인 하였다.

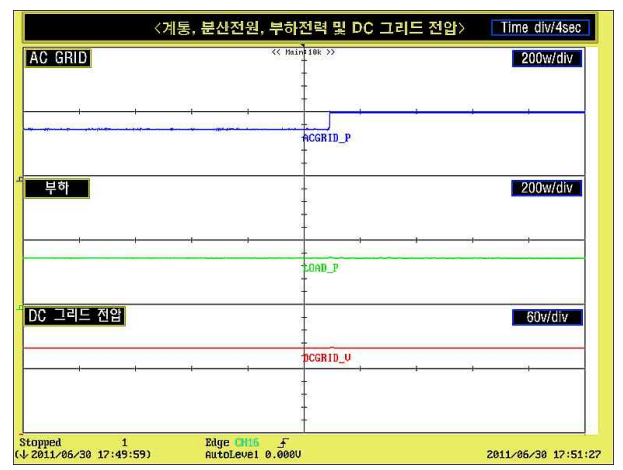

(a) 계통, 분산전원, 부하전력 및 $\mathrm{DC}$ 그리드 전압

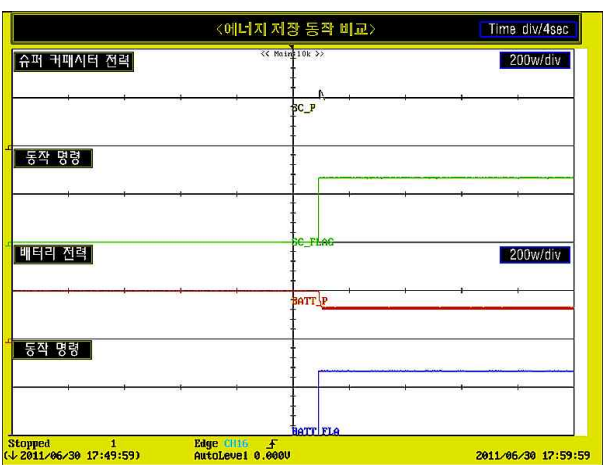

(b) 에너지 저장 동작 비교

그림 14 계통연계에서 단독운전으로의 전환

Fig. 14 Mode change from Grid-tied to Islanded Operation

그림 15 에 단독운전 실험결과를 나타내었다. 단독운 전 시에는 배터리에서 상위제어기로부터 전력레퍼런스 
를 하달 받아 전력관리를 수행하며 슈퍼 커패시터에서 전압제어를 수행하면서 배터리의 느린 반응에 대한 부 분을 보상해주게 된다. 그림 15(a)에 분산전원, 부하전 력 및 $\mathrm{DC}$ 그리드 전압을 나타내었다. 충전 시 배터리 의 SOC 상한치에 달하였을 때 상위제어기로부터 전송 되는 연료전지의 전력 지령치 조정에 의해 분산전원 출력의 합이 줄어들고 있는 것을 확인할 수 있다. 그 림 15(b),(c)에 에너지 저장의 파형을 나타내었다. 배터 리가 전력관리를 수행하면서 충·방전 동작이 천이되는 시점에서 과도분이 발생할 때에 슈퍼커패시터에서 2차 적으로 과도분을 충당해주고 있으며 배터리는 전력관 리를 원활히 수행하고 있는 것을 확인하였다.

실험결과를 통해서 제안하는 $\mathrm{DC}$ 마이크로그리드는 고속 통신을 이용한 운용관리에 의하여 분산전원 및 에너지저장의 효율적인 제어가 가능하고 부하로 안정 적으로 전력을 공급함과 동시에 $\mathrm{DC}$ 그리드의 전압관 리를 원활히 수행함을 확인하였다. 따라서 소규모 CAN그룹과 IEC 61850 연계에 있어서 신뢰도 높은 통 신 시스템을 구성했다고 볼 수 있으며 이로 인해 마이 크로그리드의 빠른 응답성과 높은 안정성을 얻을 수 있었다.

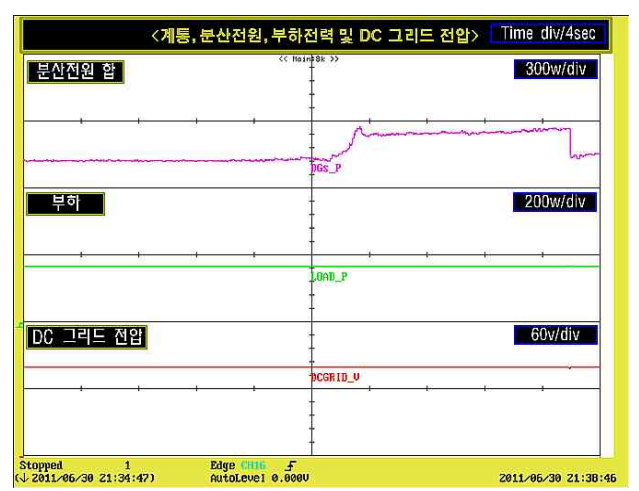

(a) 계통, 분산전원, 부하전력 및 DC 그리드 전압

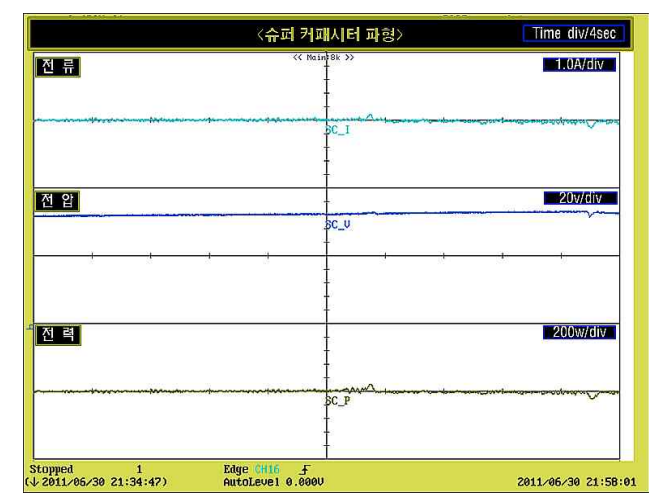

(b) 슈퍼 커패시터 파형

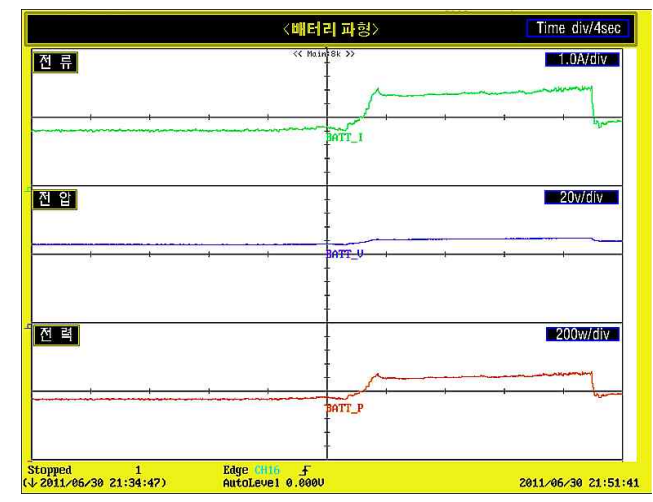

(c) 배터리 파형

그림 15 단독운전 실험 결과

Fig. 15 Experiment result in Islanded Operation

\section{6. 결 론}

본 논문에서는 분산전원으로 풍력과 태양광, 에너지 저장으로 배터리와 슈퍼커패시터, 직류부하, 그리고 교 류연계전력망으로 구성된 $\mathrm{DC}$ 마이크로그리드에서 신 뢰도 높은 통신망을 기반으로 한 시스템의 동작을 분 석한 내용에 대해 기술하고 있다. $3 \mathrm{~kW}$ 급 $\mathrm{DC}$ 마이크 로그리드 하드웨어 시뮬레이터를 제작하여 실험적으로 시스템의 동작을 분석하고 에너지 관리 시스템 성능을 검증하였다.

개발한 $\mathrm{DC}$ 마이크로그리드 하드웨어 시뮬레이터는 고속 통신망을 사용하여 마이크로그리드를 운용함에 있어서 높은 신뢰도와 안정성을 얻을 수 있었으며 $\mathrm{DC}$ 선로에 다른 전원이나 부하가 추가되어도 동작에 영향 을 받지 않으면서, 연계되어 있는 교류계통에 사고가 발생하여도 안정적인 전력운용이 가능하다.

본 연구는 중소기업청의 산학연 공동기술개발 사업(과제번호:000454680111)의 지원에 의하여 이 루어진 연구로서, 관계부처에 감사드립니다.

\section{참 고 문 헌}

[1] D. Salomonsson, L. Sode, A. Sannino, "An Adaptive Control System for a DC Microgrid for Data Centers", Industry Applications Conference, Sept. 23-27, 2007.

[2] H. Kakigano, Y. Miura, T. Ise, R. Uchida" DC Micro-grid for Super High Quality Distribution 
-System Configuration and Control of Distributed Generation and Energy Storage Devices-", IEEE PESC'06, June 18-22, 2006.

[3] P. Biczel, "Power Electronic Converters in DC Microgrid", IEEE CPE'07 (Compatibility in Power Electronics 2007), Gdynia, Poland, May 29-June 01, 2007.

[4] F. Katiraei, R. Iravani, P. Lehn, "Micro-grid autonomous operation during and subsequent to islanding process" IEEE Trans. on Power Delivery, Vol. 20, No. 1, Jan 2005.

[5] P. Piagi, R.H. Lasseter, "Autonomous control of microgrids", Power Engineering Society General Meeting, Oct, 2006.

[6] Bi. Rui, Ding. Ming, Xu. Ting Ting, "Design of common communication platform of microgrid", Power Electronics for Distributed Generation Systems (PEDG), June 16-18, 2010.

[7] A. Ruiz-Alvarez, A. Colet-Subirachs, O. Gomis-Bellmunt, J.M. Fernàndez -Mola, J. Ló pez-Mestre, A. Sudria -Andreu, "Design, management and comissioning of a utility connected microgrid based on IEC 61850", Innovative Smart Grid Technologies Conference Europe (ISGT Europe), Oct 11-13, 2010.

[8] Y. Ito, Y. Zhongqing, H. Akagi, "DC microgrid based distribution power generation system", Power Electronics and Motion Control Conference, Vol. 3, pp. 1740 - 1745, Aug 14-16, 2004.

[9] Ji-Heon Lee, Hyun-Jun Kim, Byung-Moon Han, Yu-Seok Jeong, Hyo-Sick Yang and Han-Ju Cha, "DC Micro-grid Operational Analysis with a Detailed Simulation Model for Distributed Generations," Journal of Power Electronics, vol. 11, no. 3, pp.350-359, 2011.

\section{저 자 소 개}

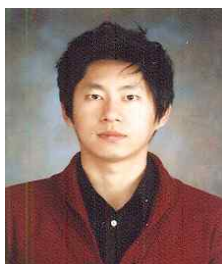

이 지헌 (李知 憲)

1983년 12월 19일생. 2008년 명지대 전 기공학과 졸업. 2008년 2010년 동 대학 원 전기공학과 졸업(석사). 2010년 현재 동 대학원 전기공학과 박사과정.

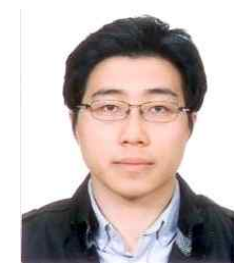

김원 용(金元溶)

1985년 5월 19일생. 2009년 대덕대학 전 기과 졸업. 2009년 2011년 명지대학교 대학원 전기공학과 졸업(석사). 2011년 현재 동 대학원 전기공학과 박사과정.

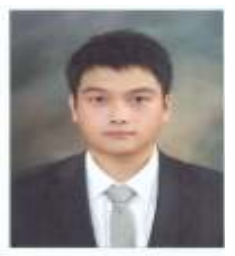

\section{김 종 원 $($ 金鍾元)}

1983년 10월 24일생. 2011년 명지대 전기 공학과 졸업. 2011년 현재 동 대학원 전 기공학과 석사과정.

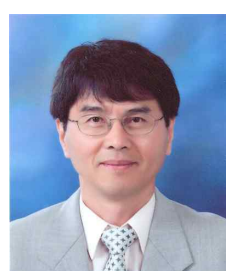

\section{한병 문(韓炳文)}

1976년 서울대 전기공학과 졸업. 1988년 미 아리조나 주립대 대학원 전기공학과 졸업(석사). 1992년 동 대학원 전기공학과 졸업(공박). Westinghouse 중앙연구소 선 임연구원. 현재 명지대 전기공학과 정교 수. 당 학회 회장. 